\title{
Development of novel LL-37 derived antimicrobial peptides with LPS and LTA neutralizing and antimicrobial activities for therapeutic application
}

\author{
Marja J. Nell ${ }^{a, d, *}$, G. Sandra Tjabringa ${ }^{b}$, Amon R. Wafelman ${ }^{c}$, Ruud Verrijk ${ }^{d}$, \\ Pieter S. Hiemstra ${ }^{b}$, Jan W. Drijfhout ${ }^{e}$, Jan J. Grote ${ }^{a}$ \\ ${ }^{a}$ Department of Otorhinolaryngology, Leiden University Medical Center, Leiden, The Netherlands \\ ${ }^{\mathrm{b}}$ Department of Pulmonology, Leiden University Medical Center, Leiden, The Netherlands \\ ${ }^{c}$ Department of Clinical Pharmacy and Toxicology, Leiden University Medical Center, Leiden, The Netherlands \\ d OctoPlus Technologies B.V., Zernikedreef 12, 2333 CL, Leiden, The Netherlands \\ e Immunohematology \& Blood Transfusion, Leiden University Medical Center, Leiden, The Netherlands
}

\section{A R T I C L E I N F O}

\section{Article history:}

Received 19 July 2005

Received in revised form

27 September 2005

Accepted 28 September 2005

Published on line 7 November 2005

Keywords:

Antimicrobial peptide

LL-37

Lipopolysaccharide

Lipoteichoic acid

Antimicrobial activity

Upper airway infections

\begin{abstract}
A B S T R A C T
New peptides for lipopolysaccharide (LPS) and lipoteichoic acid (LTA) neutralization in upper respiratory tract infections were developed and evaluated in terms of efficacy and safety for application in humans. Based on the sequence of the human antimicrobial peptide LL-37 we developed and investigated length variants, substitution analogues and modifications to stabilize the peptides to prevent enzymatic degradation and to improve efficacy. The most promising peptide appears $\mathrm{P} 60.4$, a 24 amino acid peptide with similar efficacy as LL-37 in terms of LPS and LTA neutralization and lower pro-inflammatory activity. In addition, the acetylated and amidated version of this peptide shows no toxicity and displays higher or equal antimicrobial activity compared to LL-37.
\end{abstract}

(C) 2005 Elsevier Inc. All rights reserved.

\section{Introduction}

Chronic upper airway infections affect a large part of the population [45]. Children may suffer from long-term effects with respect to the development of speech and cognitive abilities because of the hearing loss that accompanies otitis media with effusion (OME) [16]. Chronic sinusitis seriously affects the state of well being of these patients $[6,14]$. Nowadays, most patients with upper airway infections are treated with antibiotics. However, due to the growing resistance of bacteria for conventional antibiotics [17] it is necessary to develop alternative and more efficient strategies in the battle against chronic upper airway infections.

In a large part of these infections bacterial products, like lipopolysaccharide (LPS) from Gram-negative bacteria and lipoteichoic acid (LTA) from Gram-positive bacteria, are involved $[15,28]$. These products can induce an inflammatory reaction in the middle ear or in the sinuses and can cause injury to the mucosa of the upper airway epithelia $[25,26]$.

Antimicrobial peptides play an important role in innate host defense, and this is believed to be particularly important at mucosal surfaces that form the initial barrier between the

\footnotetext{
* Corresponding author. Tel.: +31 71524 4044; fax: +31 715244043.

E-mail address: nell@octoplus.nl (M.J. Nell). 
host and the external environment. Defensins and cathelicidins are the principal human antimicrobial peptides. They are mainly produced by neutrophils and epithelial cells, and have the capacity to kill and/or inactivate bacteria, fungi, and enveloped viruses in vitro $[18,47]$. The only member of the cathelicidin family identified in humans is hCAP18 (human cationic antibacterial protein of $18 \mathrm{kDa}$ ), and its carboxyterminal antibacterial peptide, called LL-37, which comprises 37 amino acid residues [12]. hCAP18 is present in neutrophils, and is expressed throughout epithelia in many organs, including surface epithelia of the airways and submucosal glands [2]. LL-37 is considered to play an important role in the first line of defense against local and systemic infection and in systemic invasion of pathogens at sites of inflammation and wounds [3]. It has been shown to have a broad antimicrobial activity and it is able to neutralize LPS and LTA $[34,42]$. On the other hand, LL-37 has also been shown to have chemotactic effects on host cells $[9,27]$.

Since LL-37 is suggested to play a role in innate host defense at mucosal surfaces, we investigated the therapeutic potential of synthetic peptides that we developed based on the sequence of LL-37. It has been suggested that the activity of LL-37 is related to its amphipatic helical structure. We therefore developed length variants with predicted improved amphipatic character.
Our aim was to obtain shorter peptides with improved or similar LPS and LTA neutralizing activities as LL-37, but with lower chemotactic properties. The efficacy was measured by LPS neutralization in a limulus amoebocyte lysate (LAL) assay and a whole blood IL-8 release assay (WB assay). LTA neutralization was also measured with a WB assay. To determine whether our synthetic peptides, designed to neutralize inflammation, would potentially promote immunity and inflammation we assessed their capacity to activate $\mathrm{T}$ cells (in an Elispot and a $\mathrm{T}$ cell proliferation assay), tested extracellular signal-regulated kinase (ERK)-activation of epithelial cells, and measured chemotaxis of neutrophils. In addition, we studied the toxicity and the antibacterial and antifungal activity of a selected peptide.

\section{Materials and methods}

\subsection{Preparation and characterization of synthetic peptides}

\subsubsection{Peptide development}

To develop peptide derivatives of LL-37 with improved or similar LPS and LTA neutralizing activities, we first analyzed 20 different 22-amino acid peptides spanning the LL-37 sequence (Table 1). The peptides were tested for their LPS

Table 1 - LPS neutralizing activity of LL-37 derived synthetic peptides

\begin{tabular}{|c|c|c|}
\hline Peptide & Sequence & Activity IC50 $(\mu \mathrm{M})^{\mathrm{a}}$ \\
\hline \multirow[t]{12}{*}{ LL-37 } & LLGDFFRKSKEKIGKEFKRIVQRIKDFLRNLVPRTES & 0.29 \\
\hline & LLGDFFRKSKEKIGKEFKRIVQ & $>3$ \\
\hline & LGDFFRKSKEKIGKEFKRIVQR & $>3$ \\
\hline & GDFFRKSKEKIGKEFKRIVQRI & $>3$ \\
\hline & DFFRKSKEKIGKEFKRIVQRIK & $>3$ \\
\hline & FFRKSKEKIGKEFKRIVQRIKD & $>3$ \\
\hline & FRKSKEKIGKEFKRIVQRIKDF & $>3$ \\
\hline & RKSKEKIGKEFKRIVQRIKDFL & $>3$ \\
\hline & KSKEKIGKEFKRIVQRIKDFLR & $>3$ \\
\hline & SKEKIGKEFKRIVQRIKDFLRN & $>3$ \\
\hline & KEKIGKEFKRIVQRIKDFLRNL & $>3$ \\
\hline & EKIGKEFKRIVQRIKDFLRNLV & $>3$ \\
\hline Selected 22-mer & KIGKEFKRIVQRIKDFLRNLVP & 1.20 \\
\hline Selected 22-mer & IGKEFKRIVQRIKDFLRNLVPR & 1.52 \\
\hline Selected 22-mer & GKEFKRIVQRIKDFLRNLVPRT & 1.75 \\
\hline \multirow{2}{*}{ Selected 22-mer } & KEFKRIVQRIKDFLRNLVPRTE & 1.49 \\
\hline & EFKRIVQRIKDFLRNLVPRTES & $>3$ \\
\hline 25 -mer & KIGKEFKRIVQRIKDFLRNLVPRTE & 0.61 \\
\hline 24-mer & KIGKEFKRIVQRIKDFLRNLVPRT & 0.78 \\
\hline $\mathrm{P} 60$ & IGKEFKRIVQRIKDFLRNLVPRTE & 0.48 \\
\hline 23-mer & KIGKEFKRIVQRIKDFLRNLVPR & 0.84 \\
\hline 23-mer & IGKEFKRIVQRIKDFLRNLVPRT & 0.48 \\
\hline \multirow[t]{4}{*}{ 23-mer } & GKEFKRIVQRIKDFLRNLVPRTE & 0.71 \\
\hline & IGKEFKRIVQRIKDFLRNLVRPLR & 1.07 \\
\hline & IGKEFERIVQRIKDFLRNLVPRTE & 1.78 \\
\hline & IGKEFKRIVERIKDFLRNLVRPLR & 1.10 \\
\hline \multirow[t]{6}{*}{ P60.4 } & IGKEFKRIVERIKRFLRELV $\underline{\text { RPLR }}$ & 0.55 \\
\hline & IGKEFKRIVËRIKRFLREELVPRTES & 1.75 \\
\hline & IGKLFKRIVQRIKDFLRNLVPRTES & 1.39 \\
\hline & IGKEFKRIVQLIKDFLRNLVPRTES & 1.29 \\
\hline & IGKLFKRIVQLIIKDFLRNLVPRTES & 0.81 \\
\hline & IGKEFKRIVERIKDFLRELVPRTES & 2.00 \\
\hline
\end{tabular}


(A)

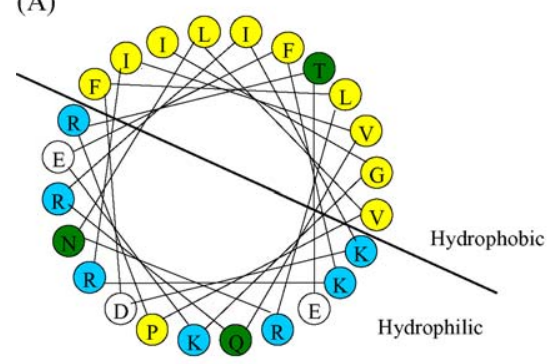

(B)

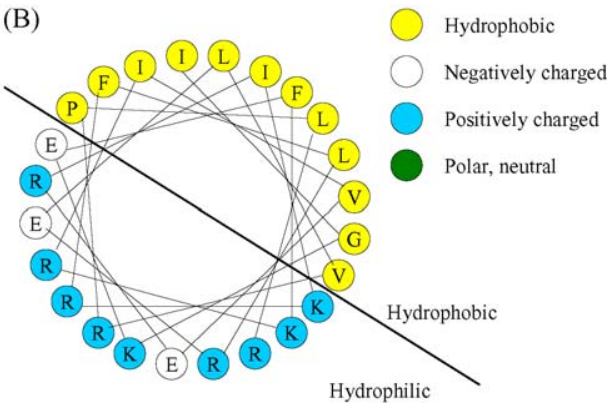

Fig. 1 - Schematic helical wheel representations of the synthetic peptides (A) P60, which is an original part of LL-37 (amino acids $\mathrm{I}^{14}$ to $\mathrm{E}^{36}$ ) and (B) P60.4, the modified peptide derived from P60.

and LTA neutralizing capacities. From the four most potent peptides we synthesized one 25-mer, two 24-mers, and three 23-mers. One of the 24-mers showed good LPS and LTA neutralizing properties and was called P60. From this peptide, 10 variants were made with several amino acid modifications in order to increase amphipaticity and stability. In Fig. 1 helical wheel representations of $\mathrm{P} 60$ and $\mathrm{P} 60.4$ are shown to illustrate the expected enhanced amphipaticity. Variant P60.4 and P60 showed the best neutralizing capacities and were further investigated in detail in this study. A more stable variant of $\mathrm{P} 60$, wherein the $\mathrm{N}$-terminal part is acetylated and the $\mathrm{C}$ terminal part is amidated (P60-Ac) was also studied. For the toxicity studies, P60.4 in acetylated and amidated form (P60.4Ac) was used. In the ototoxicity study the peptide was solved in a formulation solution (7\% Macrogol 10,000 in isotone [ $\mathrm{NaCl}]$ preserved [0.02\% benzalkonium chloride and $\left.0.1 \% \mathrm{Na}_{2} \mathrm{EDTA}\right]$ $20 \mathrm{mM}$ phosphate $\mathrm{pH}$ 5.5), which was developed to serve as future eardrop formulation.

\subsubsection{Peptide synthesis}

Peptides were synthesized by solid phase strategies on an automated multiple peptide synthesizer (SyroII, MultiSyntech, Witten, Germany). Tentagel S AC (Rapp, Tübingen, Germany), a graft polymer of polyethylene glycol and polystyrene was used as a resin (loading 0.2 meq, particle size $90 \mu \mathrm{m}$ ) [31,35]. Repetitive couplings were performed by adding a 6-fold molar excess (based on the resin loading) of a $0.60 \mathrm{M}$ solution of the appropriate 9-fluorenylmethoxycarbonyl (Fmoc) amino acid $[7,10,11]$ in $\mathrm{N}$-methylpyrrolidone (NMP), a 6 -fold molar excess of $0.67 \mathrm{M}$ benzotriazole-1-yl-oxy-tris-pyrrolidino-phosphonium hexafluorophosphate (PyBOP) [8] in NMP and a 12-fold molar excess of $N$-methylmorpholine (NMM) in NMP 2/1 (v/v) to the reaction vessel. Side chain protection was as follows: tBu for D, E, S, T; Boc for K; Trt for N, Q; Pmc for R. Fmocdeprotection was performed by adding three times piperidine/ NMP $1 / 4(v / v)$ to each reaction vessel. Coupling- and deprotection-times were $45 \mathrm{~min}$ and three times $3 \mathrm{~min}$, respectively. Washings after couplings and Fmoc-deprotections were performed six times with NMP. Amidation of the peptide was obtained by using Tantagel S AM (Rapp, Tübingen, Germany), acetylation was performed by coupling acetic acid. After synthesis the peptidyl resins were washed extensively with NMP, dichloromethane, dichloromethane/ether 1/1 (v/v) and ether, respectively, and air-dried. Peptidyl resins were cleaved and side chain deprotected in trifluoroacetic acid (TFA)/water 95/5 (v/v) for $2.5 \mathrm{~h}(1.5 \mathrm{ml} / 10 \mu \mathrm{mol}$ peptide), the resin was removed by filtration and the peptide was precipitated from the TFA solution with ether/pentane 1/1 (v/v) $(10 \mathrm{ml} / 10 \mu \mathrm{mol}$ peptide). The solution was cooled for $1 \mathrm{~h}$ at $-20^{\circ} \mathrm{C}$ and the precipitated peptide was isolated by centrifugation $\left(-20^{\circ} \mathrm{C}, 2500 \times \mathrm{g}, 10 \mathrm{~min}\right.$.). After washing and vortexing of the pellet with $10 \mathrm{ml}$ ether/pentane $1 / 1(\mathrm{v} / \mathrm{v})$ and isolation by the same procedure, the peptides were air dried at room temperature for $1 \mathrm{~h}$. Peptides were dissolved in $2 \mathrm{ml}$ water or $2 \mathrm{ml} 10 \mathrm{vol} \%$ acetic acid, the solution was frozen in liquid nitrogen for about $5 \mathrm{~min}$ and subsequently lyophilized while being centrifuged (1300 rpm, 8-16 h).

\subsubsection{RP-HPLC analysis}

Lyophilized peptides were dissolved in $10 \mathrm{vol} \%$ acetic acid $(1 \mathrm{mg} / \mathrm{ml})$ and a sample of $20-50 \mu \mathrm{l}$ was analyzed on a Waters LCM-1 system equipped with a CC 125/4 nucleosil 100-5 $C_{18}$ AB column (Macherey-Nagel, Düren, Germany). A ternary gradient system was used of A: water, B: acetonitrile, and C: 2 vol\% TFA in water. For RP-HPLC analysis a linear gradient was applied of $\mathrm{A} / \mathrm{B} / \mathrm{C} 90 / 5 / 5$ to $\mathrm{A} / \mathrm{B} / \mathrm{C} 20 / 75 / 5$ in $22 \mathrm{~min}$. The flow was $1.0 \mathrm{ml} / \mathrm{min}$ and detection was at $214 \mathrm{~nm}$. Peak integration of the chromatogram between 4 and 22 min was performed and peptide purity was defined as the peak area of the peptide compared to the total peak area.

\subsubsection{Maldi-Tof mass spectrometry analysis}

The peptide solutions were diluted 1:100 with acetonitrile/ water/TFA $50 / 50 / 0.2(\mathrm{v} / \mathrm{v} / \mathrm{v})$ and $1 \mu \mathrm{l}$ of each solution was mixed with $1 \mu \mathrm{l}$ of a $10 \mathrm{mg} / \mathrm{ml}$ solution of $\alpha$-cyano-4-hydroxycinnamic acid (4-ACH) in acetonitrile/water/TFA 50/50/0.2 (v/v/v) containing a mass reference peptide (VNTPEHVVPYGLGSPSRS, bovine big-endothelin (22-39), $\mathrm{MH}_{\mathrm{av}}{ }^{+}=1897.10$ ). The mixtures were applied to a sample slide, allowed to dry and crystallize (about $10 \mathrm{~min}$ ) and applied to the mass spectrometer (Voyager DE-Pro, PerSeptive Biosystems, Framingham, USA). The instrument was used in linear mode with an acquisition mass range of $500-5000 \mathrm{Da}$ and 50 shots/ spectrum $(3 \mathrm{~Hz})$ were applied at a laser intensity of 2000 . Measured average masses were corrected based on the mass of the reference peptide and subsequently compared to calculated average masses.

\subsection{LPS neutralization assays}

The synthetic peptides were examined for LPS neutralizing activity in a limulus amoebocyte lysate (LAL) assay and in a 
whole blood assay. For the LAL assay, peptides in concentrations from 0.125 to $16 \mu \mathrm{g} / \mathrm{ml}$, were incubated with $1 \mathrm{ng} / \mathrm{ml} \mathrm{LPS}$ (from Salmonella typhi; Sigma Chemicals, Zwijndrecht, The Netherlands) for $30 \mathrm{~min}$ at $37^{\circ} \mathrm{C}$ in a 96-well plate (\#3596; Costar, Cambridge, MA). Residual LPS activity was detected using the LAL assay (Bio Whittaker Inc., Walkersville, MD).

For the whole blood assay, heparinized blood was collected by venipuncture into heparinized tubes (Becton Dickinson, Plymouth, UK). After preincubation of $25 \mu \mathrm{l} 500 \mathrm{ng} / \mathrm{ml}$ LPS (final concentration $1 \mathrm{ng} / \mathrm{ml}$ ) with $25 \mu$ l peptide (final concentrations $0.125-16 \mu \mathrm{g} / \mathrm{ml})$ for $30 \mathrm{~min}$ at $37^{\circ} \mathrm{C}$, blood $(200 \mu \mathrm{l})$ was added in a 96-well plate (\#655180; Greiner, Alphen a/d Rijn, The Netherlands). Subsequently, the blood was stimulated and incubated with the LPS mixture for $24 \mathrm{~h}$ at $37^{\circ} \mathrm{C}$. After centrifugation for $8 \mathrm{~min}$ at $1200 \mathrm{rpm}$, plasma was collected and stored at $-20{ }^{\circ} \mathrm{C}$ until analysis for IL-8 levels by ELISA (BioSource Europe S.A., Nivelles, Belgium).

\subsection{LTA neutralization assays}

For the LTA neutralization, a whole blood assay was performed as described for LPS neutralization. Peptides were preincubated in a final concentration of $50 \mathrm{ng} / \mathrm{ml} \mathrm{LTA}$ (from Staphylococcus aureus; Sigma Chemicals, Zwijndrecht, The Netherlands). Plasma was stored at $-20^{\circ} \mathrm{C}$ until analysis for IL-8 levels by ELISA (BioSource Europe S.A., Nivelles, Belgium).

\subsection{T cell assays}

\subsubsection{Isolation of PBMC from heparinized blood}

To test the synthetic peptides in $\mathrm{T}$ cell assays, heparinized blood was acquired from three different families, which included a total of four adults and four children. Peripheral blood mononuclear cells (PBMC) were obtained by Ficoll gradient centrifugation by layering $10 \mathrm{ml}$ of Ficoll under $35 \mathrm{ml}$ of PBS-diluted heparinized blood. PBMC were collected from the interface and washed twice with PBS before dilution in Iscove's Modified Dulbecco's Medium (Gibco Life Technologies, Breda, The Netherlands) containing $10 \%$ pooled human AB serum, 2 mM glutamine (Bio Whittaker Inc., Walkersville, $\mathrm{MD}$ ), $100 \mathrm{IU} / \mathrm{ml}$ penicillin (Bio Whittaker Inc.) and $100 \mathrm{IU} / \mathrm{ml}$ streptomycin (Bio Whittaker Inc.) (IMDM complete).

\subsubsection{T cell proliferation assay}

For $\mathrm{T}$ cell proliferation, 150,000 PBMC were cultured in the absence or presence of various concentrations $(1,10$, and $100 \mu \mathrm{g} / \mathrm{ml}$ ) of synthetic peptides for 5 days in 96-well round bottom plates (Costar Inc. Cambridge, MA) in a final volume of $150 \mu \mathrm{l}$ IMDM complete. As a positive control, PBMC were cultured in the presence of $25 \mathrm{U} / \mathrm{ml}$ recombinant IL-2. During the final 20 h of culture, PBMC were pulsed with $\left[{ }^{3} \mathrm{H}\right]$ thymidine $\left(0.5 \mu \mathrm{Ci} /\right.$ well), after which ${ }^{3} \mathrm{H}$-incorporation was measured by liquid scintillation counting. Results are expressed as mean counts per minute (cpm) of triplicate wells.

\subsubsection{Elispot assay}

For detection of the T cell cytokines IFN $\gamma$ and IL-10 by Elispot analysis, $1.5 \times 10^{6}$ PBMC were cultured in $0.5 \mathrm{ml}$ IMDM complete in the absence or presence of various concentrations of synthetic peptide $(2.5$ and $25 \mu \mathrm{g} / \mathrm{ml})$. As a positive control
PBMC were stimulated with $10 \mu \mathrm{g} / \mathrm{ml}$ pokeweed mitogen (PWM). After $48 \mathrm{~h}$ of culture, PBMC were harvested by gently rinsing the wells with warm IMDM to collect non-adherent cells, which were washed in a large volume of IMDM. PBMC were subsequently plated on antibody-precoated ELISA plates and cultured for $5 \mathrm{~h}$ in IMDM supplemented with $2 \%$ pooled human $\mathrm{AB}$ serum at $37^{\circ} \mathrm{C} 5 \% \mathrm{CO}_{2}$, after which the plates were developed according to the manufacturer's protocol (UCyTech, Utrecht, The Netherlands). Spots were counted on an Olympus microscope and analyzed with Olympus Micro Image 4.0 software (Paes Nederland, Zoeterwoude, The Netherlands). Results are expressed as mean spot numbers per well of triplicate wells.

\subsection{ERK1/2-activation}

Cells from the muco-epidermoid lung carcinoma cell line NCIH292 (ATCC, Rockville, MD) were cultured in 24- or 6-well tissue culture plates in RPMI1640 medium (Gibco, Grand Island, NY) supplemented with $2 \mathrm{mM}$ L-glutamine (Bio Whittaker, Walkersville, MD), $20 \mathrm{U} / \mathrm{ml}$ penicillin (Bio Whittaker), $20 \mu \mathrm{g} / \mathrm{ml}$ streptomycin (Bio Whittaker) and 10\% (v/v) heat-inactivated fetal calf serum (Gibco). After reaching near-confluence, cells were cultured overnight in serum-free medium. Cells were subsequently stimulated for $15 \mathrm{~min}$ with indicated stimuli. Cellular lysates were prepared using lysis buffer $(0.5 \%$ [v/v] Triton X-100, 0.1 M Tris- $\mathrm{HCl} \mathrm{pH} \mathrm{7.4,} 100 \mathrm{mM} \mathrm{NaCl}, 1 \mathrm{mM} \mathrm{MgCl}$, $1 \mathrm{mM} \mathrm{Na} \mathrm{VO}_{4}$, mini complete protease inhibitor cocktail [Boeringer Mannheim, Roche, Basel, Switzerland]). Samples were subjected to SDS-PAGE on a 10\% glycine-based gel. Resolved proteins were transferred to a polyvinylidene difluoride (PVDF) membrane, and non-specific binding sites were blocked by PBS/0.05\% Tween-20/1\% casein. The blots were incubated with rabbit polyclonal antibodies against phosphorylated ERK-1/2 (New England Biolabs, Beverly, MA), and secondary horseradish peroxidase conjugated anti-rabbit IgG antibodies. The enhanced chemoluminescent (ECL) Western blotting detection system (Amersham Pharmacia Biotech, Upsala, Sweden) was used to reveal immunoreactivity.

\subsection{Chemotaxis assay}

Neutrophils were isolated from peripheral blood from healthy volunteers using Percoll density gradient centrifugation (density: $1.082 \mathrm{~g} / \mathrm{ml}$ ) as previously described [44]. Cells were resuspended at a concentration of $2.5 \times 10^{6}$ cells $/ \mathrm{ml}$ in assay buffer (20 mM N-2-hydroxyethylpiperazine-N'-2-ethanesulfonic acid [Hepes buffer; $\mathrm{pH}$ 7.4], $132 \mathrm{mM} \mathrm{NaCl}, 6 \mathrm{mM} \mathrm{KCl}$, $1.2 \mathrm{mM} \mathrm{KH}_{2} \mathrm{PO}_{4}, 1 \mathrm{mM} \mathrm{MgSO}_{4}, 5.5 \mathrm{mM}$ glucose, $0.1 \mathrm{mM} \mathrm{CaCl} 2$ and $0.5 \%$ human serum albumin [Central Laboratory of the Netherlands Red Cross Blood Transfusion Service (CLB), Amsterdam, The Netherlands]) diluted 1:1 with serum-free RPMI supplemented with $2 \mathrm{mM}$ L-glutamine, $20 \mathrm{U} / \mathrm{ml}$ penicillin, and $20 \mathrm{U} / \mathrm{ml}$ streptomycin.

Neutrophil chemotactic activity of peptides was assessed using a modified Boyden Chamber technique [19]. Briefly, $26 \mu l$ of chemotactic stimuli in assay buffer was added to the wells of the lower compartment and $50 \mu$ l of neutrophil suspension was added to the upper compartment of a 48-well chamber (Neuroprobe, Cabin John, MD, USA). Two filters separated the 
compartments: a lower filter with a pore size of $0.45 \mu \mathrm{m}$ (Millipore Products, Bedford, MA) and an upper filter with a pore size of $8 \mu \mathrm{m}$ (Sartorius Filter, San Francisco, CA). After incubation for $90 \mathrm{~min}$ at $37^{\circ} \mathrm{C}$, the upper filters were removed, fixed in ethanol:butanol $(80: 20, \mathrm{v} / \mathrm{v})$, and stained with Weigert solution. To determine neutrophil chemotactic activity, migrated neutrophils were counted in six random high-power fields $(\times 400)$. As a positive control chemotactic activity of $10^{-8} \mathrm{M} \mathrm{N}$-formyl-methionyl-leucyl-phenylalanine (FMLP; Sigma-Aldrich, St. Louis, MO) was used.

\subsection{Toxicity studies}

\subsubsection{Ototoxicity}

To evaluate the ototoxicity of peptide P60.4-Ac this peptide was tested in guinea pigs (HsdPoc:DH; Harlan, Horst, The Netherlands). Permission for these experiments was obtained from the animal experimental committee. Seven healthy male albino guinea pigs $(500-1200 \times g)$, free of external ear pathology, were used in this study. Animals were anesthetized with intraperitoneal injections of $40 \mathrm{mg} / \mathrm{kg}$ ketamine (Eurovet Animal Health B.V., Bladel, The Netherlands) and $10 \mathrm{mg} / \mathrm{kg}$ rompun (Bayer A.G., Leverkusen, Germany). After control auditory testing was performed, the auditory bullae were surgically opened to apply a small piece of spongostan to the round window membrane (RWM) and various solutions (approximately $10 \mu \mathrm{l}$ ) were added on the spongostan. The skin was sutured closed and follow-up auditory testing was performed. Application on the RWM was performed in the right ears, the left ears remained untreated. One animal received $\mathrm{PBS}$ and one animal received formulation buffer $(7 \%$ Macrogol 10,000 in isotone $[\mathrm{NaCl}]$ preserved [0.02\% benzalkonium chloride and $0.1 \% \mathrm{Na}_{2}$ EDTA] $20 \mathrm{mM}$ phosphate $\mathrm{pH}$ 5.5). Two guinea pigs received cisplatin $(0.66 \mathrm{mg} / \mathrm{ml}$ in $\mathrm{PBS}$, obtained from Sigma Chemicals, Zwijndrecht, The Netherlands), which served as a positive control for the test [39]. Peptide P60.4-Ac (2 mg/ml) was tested in PBS solution in one animal and in formulation buffer in two animals.

Auditory brainstem response (ABR) was performed prior to drug administration and directly after surgery and 3, 7, 14, and 22 days later, using a computer-based signal averaging system (Tucker-Davis Technology, Alucha, FL, USA). Guinea pigs were anesthetized and an insert earphone was placed into the external ear canal. Subcutaneous electrodes were placed over the vertex (active) and over the ipsilateral bulla (reference). Ground electrodes were placed over the neck muscles. ABRs were recorded in an electrically shielded, double-walled, radio-frequency-shielded sound chamber in response to $10 \mathrm{~ms}$ tone bursts at $1 \mathrm{kHz}$. Stimulus intensities were measured and expressed as dB. ABR threshold was defined as the lowest intensity capable of eliciting a replicable, visually detectable response. The post-treatment $A B R$ thresholds were compared to pre-treatment ABR thresholds.

\subsubsection{Toxicity}

We performed three other toxicity studies with P60.4-Ac in animals. In a primary skin irritation/corrosion study three rabbits were exposed to $0.5 \mathrm{ml}$ phosphate buffered $(20 \mathrm{mM}, \mathrm{pH}$ 7.5 , isotonic with $0.9 \% \mathrm{NaCl}$ solution) peptide solution ( $2 \mathrm{mg} /$ $\mathrm{ml})$, applied onto clipped skin for $4 \mathrm{~h}$ using a semi-occlusive dressing. Observations were made $1,24,48$, and $72 \mathrm{~h}$ after exposure. Single samples of $0.1 \mathrm{ml}$ of phosphate buffered $(\mathrm{pH}$ 7.5) peptide solution $(2 \mathrm{mg} / \mathrm{ml})$ were instilled into one eye of each of three rabbits to perform an acute eye irritation/ corrosion study. Observations were made 1, 24, 48, and $72 \mathrm{~h}$ after instillation. Finally, the toxic potential of P60.4-Ac was assessed in a single and repeated dose toxicity study in rats. The study was performed based on the ICH Harmonised Tripartite Guideline: Non Clinical Safety Studies for the Conduct of Human Clinical Trials for Pharmaceuticals, 16 July 1997. For this reason, the peptide was administered daily intravenously in escalating doses. In this phase, the maximum tolerated dose (MTD) was established. Repeated dose toxicity was also studied in the MTD phase. In the dose escalation phase nine rats were divided in three groups and received $0.4,2$, or $8 \mathrm{mg} /(\mathrm{kg}$ day) for 2 days. Clinical signs were recorded twice daily on days of dosing and 1 day after dosing, body weights were recorded prior to the first dose and 1 day after dosing. In the MTD phase, five female and five male rats received $8 \mathrm{mg} /(\mathrm{kg}$ day) for 5 consecutive days. Clinical signs were recorded twice daily on days of dosing, body weight on days 1 and 6. Clinical laboratory investigations were performed prior to necropsy. Macroscopy was performed at termination of the MTD phase.

\subsection{Antimicrobial assays}

The in vitro antibacterial and antifungal activity of P60.4-Ac and LL-37 were determined as the minimum inhibitory concentrations (MIC) by a microdilution susceptibility test in 96-well microtiter plates, according to a modified version of Hancock's "Modified MIC method for cationic antimicrobial peptides" [13]. The antibacterial activity was tested on the reference strains Escherichia coli ATCC 8739, Pseudomonas aeruginosa ATCC 9027. The antifungal activity was evaluated on Candida albicans ATCC 10231 and Aspergillus niger ATCC 14406. The antimicrobial activity assay was conducted with different concentrations of P60.4Ac and LL-37 to compare their effects on the bacterial or fungal growth. Antibacterial activity was examined using logphase cultured bacteria in Trypticase Soy Broth at $37^{\circ} \mathrm{C}$. The cultures were diluted with $10 \mathrm{mM}$ sodium phosphate buffer $\mathrm{pH}$ 7.4 to give approximately $5.0 \times 10^{6} \mathrm{CFU} / \mathrm{ml}$. Ten microliters of the diluted test strain was transferred to a 96-well plate and $100 \mu \mathrm{l}$ of the different peptide concentrations diluted in $1 \%$ Trypticase Soy Broth in $10 \mathrm{mM}$ Sodium Phosphate buffer $\mathrm{pH} 7.4$ was added to each well. The plates were incubated at $37^{\circ} \mathrm{C}$ for $24 \mathrm{~h}$ and are then scored for growth by visual inspection on a light box. They are then returned for incubation for a further $24 \mathrm{~h}$ after which time they are re-evaluated for growth. The yeast strain C. albicans was prepared as described above. The filamentous fungi A. niger was used as a spore suspension, cultured on Sabourauds Dextrose Agar plates at 20-25 ${ }^{\circ} \mathrm{C}$ for 610 days or until adequate sporulation has occurred. The spores were harvested by scrapping and if necessary the concentration was adjusted to a final concentration of $5 \times 10^{6} \mathrm{CFU} / \mathrm{ml}$.

\subsection{Statistical analysis}

LPS and LTA neutralization data are shown as mean \pm standard deviation (S.D.). Statistical significance was determined by one-way ANOVA with the Statistical Package for Social Sciences 
Table 2 - LTA and LPS neutralization \pm S.D. for the different peptides

\begin{tabular}{|c|c|c|c|}
\hline \multirow[t]{2}{*}{ Peptide } & \multicolumn{2}{|c|}{$50 \%$-LPS inhibition $(\mu \mathrm{M})$} & \multirow[t]{2}{*}{$50 \%$-LTA inhibition $(\mu \mathrm{M}), n^{\mathrm{a}}=3$} \\
\hline & LAL assay & WB assay & \\
\hline LL-37 & $0.29 \pm 0.06(n=5)$ & $0.27 \pm 0.05(n=3)$ & $0.36 \pm 0.10$ \\
\hline P60 & $0.44 \pm 0.14(n=5)$ & $0.42 \pm 0.04(n=4)$ & $0.62 \pm 0.22$ \\
\hline P60.4 & $0.51 \pm 0.18(n=5)$ & $0.62 \pm 0.17^{\mathrm{b}}(n=2)$ & $0.59 \pm 0.38$ \\
\hline P60-Ac & $0.53 \pm 0.24^{b}(n=5)$ & $0.70 \pm 0.15^{\mathrm{b}, \mathrm{c}}(n=2)$ & $0.60 \pm 0.12$ \\
\hline
\end{tabular}

(SPPS). Probability values of $P<0.05$ were considered statistically significant. To calculate $50 \%$-inhibiting values in the LPS and LTA neutralization assays, we used SlideWrite Plus for Windows version 5.01. Graphs were created using doseresponse curve fitting in Graph Pad Prism version 4.01 for Windows.

To determine a significant response in the $\mathrm{T}$ cell proliferation assay, counts per minute in the presence of stimulus were compared to the relevant medium control using one-way ANOVA (SPSS and Graph Pad Prism). Elispot responses were analyzed with the Mann-Whitney U-test in SPSS and Graph Pad Prism. Differences at $P$-values $<0.05$ were considered significant.

\section{Results}

\subsection{Synthetic peptides}

All different peptides were analyzed first in the LAL assay. The activity of all the different peptides is presented in Table 1 as $50 \%$ LPS neutralization values in $\mu \mathrm{M}$ (IC50). It was obvious that the LPS neutralizing activity of LL-37 resides primarily in the Cterminal part of the peptide. Subsequently, we tried to further improve activity by amino acid modifications. Computer analysis (Peptide Companion) showed that P60 is likely to fold into an amphipatic helix, although the amphipatic structure is not ideal. Especially, $\mathrm{P}^{21}$ and $\mathrm{T}^{23}$ seem to be "misplaced", which might be an indication that the C-terminus of $\mathrm{P} 60$ is not helical. Replacement of the C-terminal part of P60 (PRTE) by the sequence RPLR was predicted to yield better felicity. In addition, $\mathrm{Q}^{10}$ (neutral/polar) was replaced by $\mathrm{E}$ in an attempt to stabilize the helix by possible salt bridges with neighboring positive charges. $\mathrm{D}^{14}$ was replaced by $\mathrm{R}$ to increase the overall charge of the polar part of the helix. The effects of these modifications were investigated by evaluating the LPS neutralizing activity of the variants as indicated in Table 1 . Based on these results, we selected the peptides P60 and P60.4 for further detailed investigation. An acetylated and amidated variant of $\mathrm{P} 60$ was made (P60-Ac) to improve stability and tested to investigate whether this would influence the properties of the peptide. Helical wheel presentations show the optimization of the predicted amphipatic $\alpha$-helical structure of P60.4 resulting from amino acid substitutions in P60 (Fig. 1).

\subsection{LPS and LTA neutralization}

Peptides P60 and P60.4 were further examined for their efficacy in LPS neutralization with a LAL assay and a whole blood (WB) assay. Both assays showed comparable results. The peptide concentration whereby $50 \%$ of the LPS activity is inhibited is a measure of the peptide's activity (IC50); a low IC50 indicates high potency of LPS neutralization. When the 50\%-LPS inhibition results are compared, it is clear that LL-37 has the strongest activity with an IC50 of $0.29 \pm 0.06 \mu \mathrm{M}$ in the LAL assay and an IC50 of $0.27 \pm 0.05 \mu \mathrm{M}$ in the WB assay (Table 2). The activity of P60 did not differ significantly from LL-37. Peptide P60.4 showed significantly $(P<0.05)$ lower activity in the WB assay but was not significantly different from LL-37 in the LAL assay. In Fig. 2, the LPS inhibition curves determined with the LAL assay for LL37 and our synthetic peptides are plotted.

LTA neutralization was measured in a WB assay. The results show that the synthetic peptides have a comparable activity, which is not significantly different from LL-37 (Table 2). In addition, LTA neutralization as assessed by determining IC50values is comparable with LPS neutralization.

To investigate whether acetylation and amidation would influence the activity of a synthetic peptide, P60-Ac was also tested for LPS and LTA neutralization. Except from the WB assay for LPS neutralization P60-Ac did not differ significantly from P60. It appeared that stabilizing a peptide by acetylation and amidation did not influence the LPS and LTA neutralizing capacity to a large extend (Table 2; Fig. 2).

\subsection{Immunogenicity}

To explore possible immune stimulatory or pro-inflammatory activity we performed several experiments with our selected

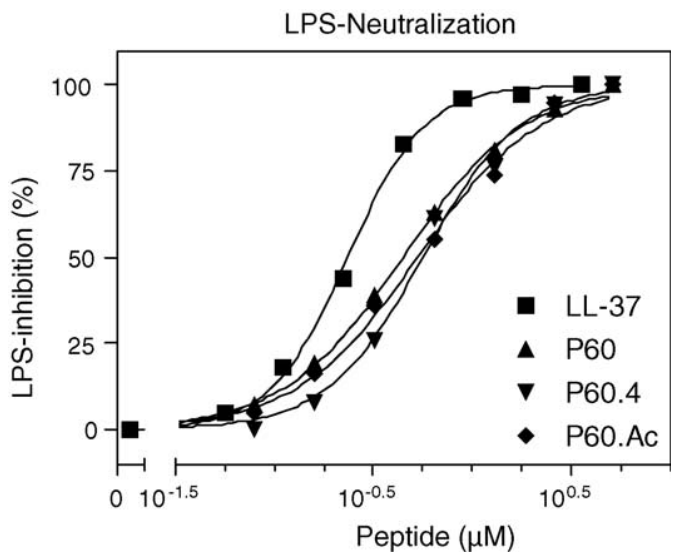

Fig. 2 - Dose-response curves of LPS neutralization by different LL-37 derived peptides and LL-37 as determined by LAL assay. 
Table 3 - Summary of the immunogenicity experiments with the synthetic peptides compared to LL-37

\begin{tabular}{lccccc} 
Compound & $\gamma$-IFN Elispot & (L-10 Elispot & T cell proliferation $^{\mathrm{a}}$ & ERK-activation $^{\mathrm{b}}$ & Chemotaxis $^{\mathrm{c}}$ \\
\hline P60 & $1 / 8$ & $4 / 8$ & $7 / 8$ & - & $76 \pm 39(n=3)$ \\
P60.4 & $3 / 8$ & $2 / 8$ & $2 / 8$ & \pm & $0 \pm 0(n=2)^{\mathrm{d}}$ \\
LL-37 & $4 / 8$ & $4 / 8$ & $6 / 8$ & + & $84 \pm 17(n=5)$ \\
P60-Ac & $3 / 8$ & $4 / 8$ & $4 / 8$ & \pm & $61 \pm 36(n=4)$
\end{tabular}

${ }^{a}$ Results are shown as number of individual donors that induced a significant $(P<0.05)$ increase when peptide-stimulated responses were compared to medium induced responses.

${ }^{\mathrm{b}}$ At $7.3 \mu \mathrm{M}$, experiment performed in duplicate.

${ }^{c}$ Values represent migration of neutrophil cells counted per six high-power fields.

d Significantly $(P<0.05)$ lower than LL-37 induced migration.

synthetic peptides. A summary of the results of these experiments is given in Table 3 .

\subsubsection{T cell assays}

The two selected synthetic peptides P60 and P60.4 were tested in an Elispot to assess cytokine production and in a $\mathrm{T}$ cell proliferation assay. For analysis of the T cell proliferation IL-2 served as a positive control and increased the mean $\mathrm{T}$ cell proliferation significantly $(P<0.01)$ (Fig. 3). A concentration of 1 or $10 \mu \mathrm{g} / \mathrm{ml}$ peptide did not induce any significant stimulation of the T cells. At $100 \mu \mathrm{g} / \mathrm{ml} \mathrm{LL}-37$ induced a significantly increased mean $T$ cell proliferation $(P<0.05)$ whereas, $P 60$ and P60.4 did not induce significant $\mathrm{T}$ cell proliferation. The synthetic peptide $\mathrm{P} 60.4$ resulted in a significantly $(P<0.05)$ lower $\mathrm{T}$ cell proliferation compared to LL-37. When donors were compared individually, LL-37 induced significant $(P<0.05)$ increased $T$ cell proliferation in six out of eight donors, $\mathrm{P} 60$ in seven out of eight donors, and P60.4 in only two out of eight donors (Table 3). The T cell proliferation of P60-Ac was not significantly different from the medium (Fig. 3).

The Elispot assay was used to evaluate the effect of our peptides on cytokine production by PBMC, thereby providing data on their putative modulating effects on immune function in vivo [43]. Compared with medium alone, no significant IFN$\gamma$ responses were detected for the peptides (Fig. 4A). When the donors were analyzed individually, LL-37 induced a significant $(P<0.05)$ increase in IFN- $\gamma$ producing T cells in four out of eight donors (Table 3). P60 induced a significant increase in one out

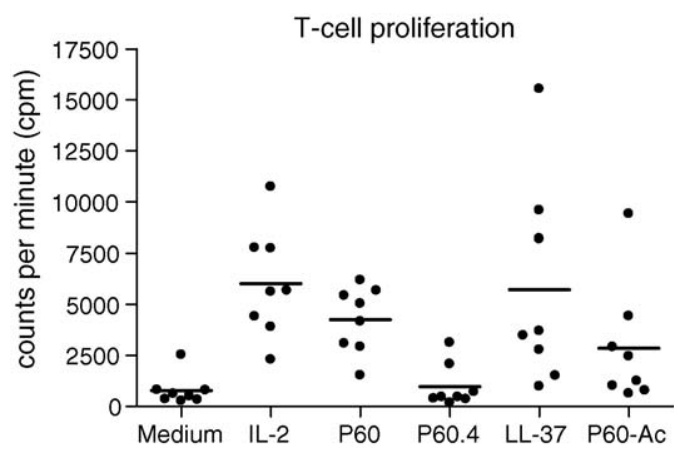

Fig. 3 - T cell proliferation of eight different donors. IL-2 $(25 \mathrm{U} / \mathrm{ml})$ serves as positive control. LL-37 and the synthetic peptides shown here were tested at $100 \mu \mathrm{g} / \mathrm{ml}$ each. Results are shown of the donors individually together with the mean values.

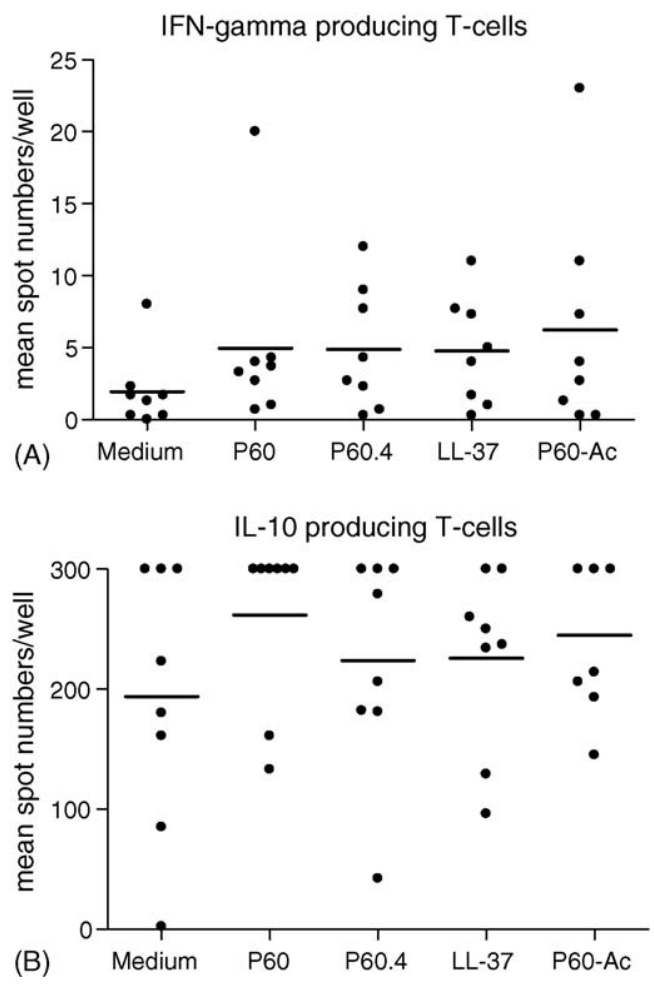

Fig. 4 - IFN- $\gamma$ (A) and IL-10 (B) responses (mean spot numbers/well) to LL-37 and the different synthetic peptides. IFN- $\gamma$ responses to $25 \mu \mathrm{g} / \mathrm{ml}$ peptide are shown. IL-10 responses to $2.5 \mu \mathrm{g} / \mathrm{ml}$ peptide are shown.

of eight donors and P60.4 in two out of eight donors. No significant IL-10 responses were detected for the peptides when compared with medium alone (Fig. 4B). LL-37 and P60 both induced a significant $(P<0.05)$ increase in IL-10 producing cells in four out of eight donors (Table 3); whereas, P60.4 induced a significant $(P<0.05)$ response in only two out of eight donors. Stimulation with P60-Ac did not induce significantly different mean values for IFN- $\gamma$ producing $\mathrm{T}$ cells and IL-10 producing cells compared to the other peptides or compared to medium alone.

\subsubsection{Chemotaxis assay}

Cellular migration of neutrophils due to chemotaxis induced by our selected synthetic peptides is represented in Fig. 5 and Table 3. The positive control, FMLP, induced the highest cellular 


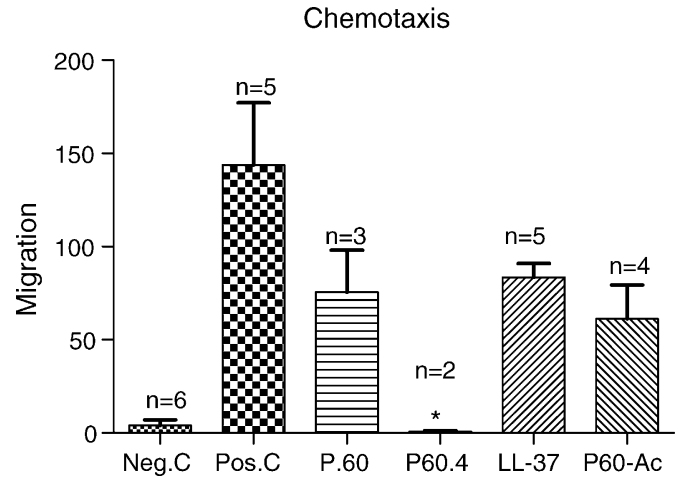

Fig. 5 - Average neutrophil migration response to the different peptides $\left(10^{-5} \mathrm{M}\right)$. Migration (S.E.M.) was determined as numbers of cells per six high-power fields. "Significantly $(P<0.05)$ lower than LL-37 induced migration; $n$ : number of performed experiments, using cells from different donors.

migration. LL-37 and P60 induced a significant $(P<0.05)$ migration of neutrophils compared to medium induced migration, whereas P60.4 did not induce any migration. Acetylation and amidation of $\mathrm{P} 60$ induced no significant change in chemotaxis.

\subsubsection{ERK1/2-activation}

Possible activation of epithelial cells by the peptides was examined in the extracellular signal-regulated kinase (ERK)activation assay. ERK1/2 is part of the MAP-kinase signaling pathway, which has been shown to be involved in various cellular processes, including proliferation, differentiation, cell survival and expression of genes encoding pro-inflammatory mediators like cytokines [1]. None of the peptides, including LL-37, induced ERK-activation at a concentration of $2.4 \mu \mathrm{M}$ (Fig. 6). At 7.3 $\mu \mathrm{M}$, LL-37 induced marked phosphorylation of ERK1/2, indicative of epithelial cell activation. P60.4 induced a moderate ERK-activation at this concentration, whereas P60 did not induce clear ERK-activation. From the original Western blot and the accompanying intensity score of the ERKactivation (Table 3) it is clear that at a concentration of $7.3 \mu \mathrm{M}$ our synthetic peptides P60 and P60.4 induced a lower ERK-activation than LL-37. P60-Ac induced a moderate ERK-

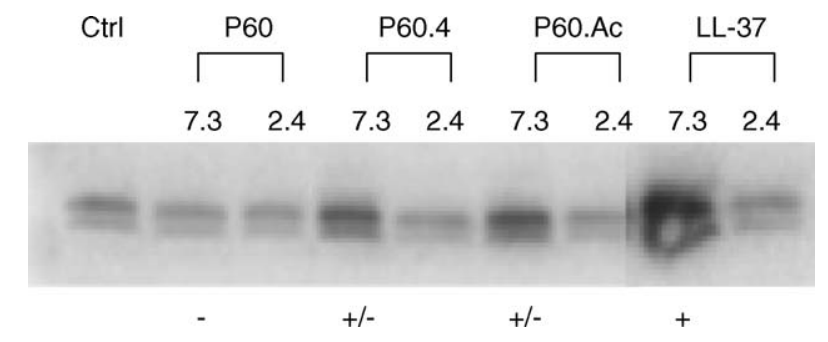

Fig. 6 - ERK1/2 activation by LPS neutralizing peptides in NCI-H292 bronchial epithelial cells. Cells were stimulated with 7.3 $\mu \mathrm{M}$ peptide (first lane for each peptide) and $2.4 \mu \mathrm{M}$ peptide (second lane). Ctrl, control lane. Below the blot the intensity scores for $7.3 \mu \mathrm{M}$ are given. Similar results were obtained in a duplicate independent experiment.

activation, which was higher than the P60 induced ERKactivation.

\subsection{In vivo toxicity studies}

P60.4 showed the most favorable results in case of immunogenicity and LL-37 comparable LPS and LTA neutralization. Since P60 and P60-Ac did not differ significantly in activity or in immunogenicity, this is indicating that acetylation and amidation of the peptides does not affect their activity in vitro. Because acetylation and amidation increases stability, and because P60.4 caused less $\mathrm{T}$ cell and neutrophil activation, toxicity studies were performed with P60.4-Ac.

\subsubsection{Ototoxicity}

Ototoxicity was measured in guinea pigs. Round window application of PBS, which was used as a control, did not result in a threshold change at 22 days after surgery. Formulation buffer resulted in a threshold change of $2 \mathrm{~dB}$ after 22 days. Cisplatin, on the other hand, induced threshold changes of, respectively, -49 and $-64 \mathrm{~dB}$, which indicate a severe hearing loss (Table 4). This part of the experiments served as a positive control for the ototoxicity study. Peptide P60.4-Ac (2 mg/ml) in PBS induced a threshold change of $-7 \mathrm{~dB} 22$ days after surgery. Both animals that received P60.4-Ac in formulation buffer produced a threshold change of $1 \mathrm{~dB}$.

\begin{tabular}{|c|c|c|c|c|c|c|c|}
\hline \multirow{2}{*}{$\begin{array}{l}\text { Group } 1 \\
\text { Post-surgery }\end{array}$} & \multirow{2}{*}{$\begin{array}{c}\text { PBS } \\
1\end{array}$} & \multicolumn{2}{|c|}{ Cisplatin } & \multirow{2}{*}{$\begin{array}{l}\mathrm{P} 60.4-\mathrm{AC}^{\mathrm{a}} \\
-2\end{array}$} & \multirow{2}{*}{ Formulation $^{\mathrm{b}}$} & \multicolumn{2}{|c|}{$\mathrm{P} 60.4-A c^{\mathrm{C}}$} \\
\hline & & -2 & -1 & & & 14 & 20 \\
\hline 3 Days & -3 & -32 & -38 & -2 & -8 & -1 & 1 \\
\hline 7 Days & -3 & -32 & -45 & 0 & $-33^{\mathrm{d}}$ & -18 & 2 \\
\hline 14 Days & 0 & -30 & -59 & -12 & -1 & 0 & 2 \\
\hline 22 Days & 0 & -49 & -64 & -7 & 2 & 1 & 1 \\
\hline $\begin{array}{l}\text { Values repres } \\
\text { a Solution i } \\
\text { b } 7 \% \text { Macro } \\
\text { c Solution ir } \\
\text { d Unreliable }\end{array}$ & $\begin{array}{l}\text { urgery } \\
\mathrm{n} \text { isot } \\
\text { ion bu } \\
\text { ments }\end{array}$ & $\begin{array}{l}\text { rese } \\
\text { wire }\end{array}$ & ben & chloride an & EDTA] $20 \mathrm{mM}$ ph & H 5.5 . & \\
\hline
\end{tabular}


Table 5 - Antimicrobial activity of P60.4-Ac compared with LL-37

\begin{tabular}{|c|c|c|c|}
\hline Organism (strain) & $\begin{array}{c}\text { Incubation } \\
\text { time (h) }\end{array}$ & Peptide & $\begin{array}{r}\mathrm{MIC}^{\mathrm{a}} \\
(\mu \mathrm{M})\end{array}$ \\
\hline \multirow[t]{4}{*}{ E. coli ATCC 8739} & 24 & LL-37 & 3 \\
\hline & & P60.4-Ac & 2 \\
\hline & 48 & LL-37 & $7^{b}$ \\
\hline & & P60.4-Ac & $3^{c}$ \\
\hline \multirow[t]{4}{*}{ P. aeruginosa ATCC 9027} & 24 & LL-37 & 3 \\
\hline & & P60.4-Ac & 3 \\
\hline & 48 & LL-37 & $14^{\mathrm{d}}$ \\
\hline & & P60.4-Ac & $6^{\mathrm{b}}$ \\
\hline \multirow[t]{4}{*}{ C. albicans ATCC 10231} & 24 & LL-37 & 12 \\
\hline & & P60.4-Ac & 6 \\
\hline & 48 & LL-37 & $>18^{\mathrm{e}}$ \\
\hline & & P60.4-Ac & $6^{f}$ \\
\hline \multirow[t]{4}{*}{ A. niger ATCC 14406} & 24 & LL-37 & $>18$ \\
\hline & & P60.4-Ac & 18 \\
\hline & 48 & LL-37 & $>18^{e}$ \\
\hline & & P60.4-Ac & $>18^{e}$ \\
\hline
\end{tabular}

${ }^{a}$ MIC was defined as the lowest concentration of peptide that inhibited the bacterial visible growth after incubation for 24 or $48 \mathrm{~h}$ at $37^{\circ} \mathrm{C}$. Results given are mean values of three independent determinations.

$\mathrm{b}$ Bactericidal at $18 \mu \mathrm{M}$

c Bactericidal at $6 \mu \mathrm{M}$.

d Bacteriostatic.

e Recovery of viable organisms was not performed, as growth in all wells was clearly visible.

${ }^{\mathrm{f}}$ Possible fungicidal at $18 \mu \mathrm{M}$, fungistatic at $6 \mu \mathrm{M}$.

\subsubsection{General toxicity}

No skin irritation was caused by $4 \mathrm{~h}$ exposure to phosphate buffered peptide solution of P60.4-Ac (data not shown). Instillation of the peptide solution resulted in redness of the conjunctivae that resolved completely within $24 \mathrm{~h}$ after instillation (data not shown). No mortality occurred in the dose escalation study with $0.4,2$, and $8 \mathrm{mg} /(\mathrm{kg}$ day). Furthermore, no clear deviations were noted in clinical signs and body weight. During the maximum tolerated dosage (MTD) phase also no mortality occurred and no clear peptide related findings were noted in clinical signs, body weight, hematology and clinical biochemistry parameters and at macroscopic examination. An intravenous MTD of peptide P60.4-Ac could not be determined but will be higher than $8 \mathrm{mg} / \mathrm{kg}$.

\subsection{Antimicrobial activity}

The antimicrobial activity of P60.4-Ac was evaluated against two Gram-negative strains and against the fungi $C$. albicans and A. niger and compared with LL-37. The MIC values for each peptide are reported in Table 5. P60.4-Ac showed a higher or equal activity against the Gram-negative strains $E$. coli and $P$. aeruginosa compared to LL-37. In some cases, bactericidal activity was also determined for both peptides. P60.4-Ac showed an MIC at $6 \mu \mathrm{M}$ against $C$. albicans and may well be fungicidal at $18 \mu \mathrm{M}$. P60.4-Ac at $18 \mu \mathrm{M}$ inhibited the germination of A. niger spores for $24 \mathrm{~h}$, whereas LL-37 shows no activity against $A$. niger.

\section{Discussion}

In this study, we have developed synthetic derivatives of the human antimicrobial peptide hCAP18/LL-37. By downsizing the LL-37 peptide to 22-mer peptides we identified four peptides with good LPS neutralizing activity. To increase the activity, six elongated variants of these four peptides were made of which peptide variant P60 displayed the most powerful LPS neutralizing activity. Subsequently, modifications of this peptide were made in order to increase the hydrophobicity and cationicity, which resulted in peptide P60.4. The LPS and LTA neutralizing capacities of P60 and P60.4 were further analyzed in a LAL assay and a whole blood assay and compared with LL-37. We found a similar neutralization capacity of the two selected peptides when compared to endogenous LL-37.

Several studies showed that the C-terminal domain of hCAP18 could neutralize various activities of LPS $[20,24,34]$ and LTA [34]. Nagaoka et al. [24] identified an 18-mer peptide derived from hCAP18/LL-37, which is also included in our 22mer peptide. By modifying hydrophobicity and cationicity of this peptide they could augment LPS neutralizing activities of this peptide. In contrast to the cytotoxic activity of the 18-mer peptide described by Nagaoka et al., our peptide appeared to show less cytotoxic activity. It needs to be noted, however, that the peptides from the study of Nagaoka et al. and our peptides were evaluated in different assays.

When biologically active peptides are used clinically in their natural form, their biologic effects are often rapidly lost in vivo due to rapid proteolytic degradation of the active form of the peptide [21]. There is evidence that this cleavage of short peptides may be markedly inhibited by modifications of the Nand C-terminal residues [30]. Modifications like acetylation or amidation on the other hand, can also inhibit or reduce the activity of peptides $[29,36]$. To improve stability, we synthesized P60-Ac, the N-terminally acetylated and C-terminally amidated variant of P60. Our results showed that the LPS and LTA neutralization activity of the acetylated and amidated peptide as well as the immunogenicity of this peptide was not markedly changed.

Cytokines are direct mediators of inflammation and influence the progress and direction of many immunological reactions. Perturbation of the balance in cytokine production is widely recognized as a critical factor in several disease states. This balance is already disturbed in the case of OME [37] and sinusitis [46]. Various antimicrobial peptides have been shown to display activities related to inflammation and induction of immunity, which are distinct from their antimicrobial and LPS neutralizing activities [18]. LL-37 is known to stimulate epithelial cells [41] and macrophages [34]. Moreover, LL-37 is chemotactic for $\mathrm{T}$ cells [9] but until now it has not yet been demonstrated that LL-37 can also stimulate $\mathrm{T}$ cell proliferation and cytokine production. In the present study, we demonstrate that LL-37 increases $\mathrm{T}$ cell proliferation and cytokine production. Furthermore, we demonstrated that $\mathrm{P} 60$ and P60.4 induce cytokine production by $\mathrm{T}$ cells to an equal or lower level than the endogenous LL-37 peptide. Based on the nature of the Elispot assay, we cannot rule out the possibility that IL-10 was derived from monocytes. In the $\mathrm{T}$ cell proliferation assay, we observed the lowest response after incubation with our peptide P60.4. The 
results indicate a lower stimulation of $\mathrm{T}$ cells by our synthetic developed peptides when compared to LL-37. We assume that this low $\mathrm{T}$ cell reactivity may be favorable because this might limit $\mathrm{T}$ cell activation in vivo.

For in vivo use of the selected LPS neutralizing peptides in upper airway infections, it is also important to explore the effects of the peptides on activation of epithelial cells. Therefore, we studied the effects of the peptides on phosphorylation of extracellular signal-regulated kinase (ERK1/2), in NCI-H292 bronchial epithelial cells. Tjabringa et al. [41] demonstrated that LL-37 activates airway epithelial cells by activating ERK1/2. Our selected synthetic peptides induced a lower activation of ERK1/2 in epithelial cells when compared to endogenous LL-37. Since excessive epithelial stimulation may lead to changes in epithelial phenotype (squamous and mucous differentiation) and inflammation, we assume that an ideal peptide should have maximal LPS neutralizing capacity and minimal stimulatory effects on epithelial cells. Therefore, it appears that our selected synthetic peptides, P60 and P60.4, may be suitable for therapeutic application in upper airway infections.

LL-37 is known to be chemotactic to neutrophils, monocytes, T cells, and mast cells [9,27]. We demonstrated a comparable chemotactic activity towards neutrophils for P60 and for LL-37. Remarkably, in this assay P60.4 did not show any chemotactic activity. These data suggest that the amino acid substitutions in $\mathrm{P} 60.4$ resulted in a decreased interaction with the formyl peptide receptor employed by LL-37 to exert its chemotactic activity [9]. Recruitment of inflammatory cells to sites of microbial invasion may be beneficial during acute infection. However, for treatment of chronic infections it is more favorable to dampen the immune response and not to attract more inflammatory cells. This consideration makes peptide $\mathrm{P} 60.4$ a very attractive candidate for further development.

Since the developed peptide was designed for use in treatment of upper respiratory tract infections, we also tested the possible ototoxicity of P60.4-Ac in a formulation solution. Some studies have demonstrated that common topical otomicrobial agents can induce cochlear hair cell damage $[4,32]$. It is also known that neutrophil cationic peptides and cationic antibiotics such as polymyxin $\mathrm{B}$ have a limited clinical use because of their potential toxicity $[33,38]$ We could demonstrate that P60.4-Ac does not induce any signs of possible ototoxicity. Additionally, we found that repeated intravenous administration of peptide P60.4-Ac to male and female rats at $8 \mathrm{mg} /(\mathrm{kg}$ day) on 5 consecutive days did not result in clear peptide related changes in clinical signs, body weight, hematology, clinical biochemistry, and macroscopic findings. Furthermore, no skin or lasting eye irritation was observed in the acute skin and eye irritation/corrosion study. So far, the results of these toxicity experiments indicate that our peptide can be used safely in further studies.

We tested the antimicrobial activity of P60.4-Ac against E. coli, P. aeruginosa, C. albicans, and A. niger. Our designed peptide P60.4-Ac showed a higher or equal antimicrobial activity than LL-37 against all the strains tested. When compared to LL-37 it seems that our designed antimicrobial peptide shows a shift in biological activity toward antimicrobial function and away from the ability to stimulate a host response. Murakami et al. [23] have also revealed this shift. They showed that human sweat contains shorter variants of LL-37 generated by proteolytic activity in sweat. Some of these peptides showed similar or enhanced antimicrobial action when compared to LL-37, but a decreased ability to stimulate IL-8 release from keratinocytes. In addition, predicted processing variants of the rat homologue of LL-37, rCRAMP, showed a similar swift in activity [40].

For treatment of upper airway infections antibiotics are still most frequently used, but over the past decade levels of bacterial resistance to antibiotics have risen dramatically [22]. As a result, there is a growing need to discover and introduce new drugs. Besides their direct antimicrobial function, antimicrobial peptides play an important role in the protection of epithelial surfaces through other activities. They have multiple roles as mediators of inflammation with impact on epithelial and inflammatory cells influencing diverse processes such as cell proliferation, immune induction, wound healing, cytokine release, and chemotaxis [18]. Antimicrobial peptides are attractive candidates for clinical development because of their selectivity, their speed of action and because bacteria may not easily develop resistance against them [5]. Furthermore, unlike many defensins, several of the cathelicidin-derived peptides retain broad-spectrum activity at physiologic or elevated salt concentrations [42]. However, the use of antimicrobial peptides can be limited by their nonselective toxicity, low stability, immunogenicity, and their costs of production.

In this study, we have developed synthetic derivatives of LL-37. One peptide, P60.4, which showed similar LPS and LTA neutralizing activity but with lower $\mathrm{T}$ cell stimulation, lower epithelial cell activation, and with much lower chemotactic capacity when compared to LL-37, was selected. In addition, a more stable acetylated and amidated form this peptide showed no signs of toxicity and had an improved antimicrobial activity when compared to LL-37. Therefore, our synthetic peptide may have therapeutic potential for bacterial and fungal infections and has potential as new therapeutic agent for upper respiratory tract infections.

\section{Acknowledgements}

The authors wish to thank A. van Halteren for performing Elispot assays, W.M.C. Klop for performing the surgery on the guinea pigs, M.J. Vonk for assisting with the auditory brainstem response measurements, and P. de Koning and W.E. Benckhuijsen for peptide synthesis, analysis, and purification.

\section{R E F E R E N C E S}

[1] Arbabi S, Maier RV. Mitogen-activated protein kinases. Crit Care Med 2002;30:S74-9.

[2] Bals R, Wang X, Zasloff M, Wilson JM. The peptide antibiotic LL-37/hCAP-18 is expressed in epithelial of the human lung where it has broad antimicrobial activity at the airway surface. Proc Natl Acad Sci USA 1998;95:9541-6.

[3] Bals R, Wilson JM. Cathelicidins-a family of multifunctional antimicrobial peptides. Cell Mol Life Sci 2003;60:711-20. 
[4] Barlow DW, Duckert LG, Kreig CS, Gates GA. Ototoxicity of topical otomicrobial agents. Acta Otolaryngol 1995;115:231-5.

[5] Boman HG. Antibacterial peptides: basic facts and emerging concepts. J Intern Med 2003;254:197-215.

[6] Brook I, Gooch III WM, Jenkins SG, Pichichero ME, Reiner SA, Sher L, et al. Medical management of acute bacterial sinusitis Recommendations of a clinical advisory committee on pediatric and adult sinusitis. Ann Otol Rhinol Laryngol 2000;109:2-20.

[7] Chan WC, White PD. In: Chan WC, White PD, editors. Fmoc solid phase peptide synthesis. Oxford: Oxford University Press; 2000. p. 41-76.

[8] Coste J, Dufour MN, Nguyen D, Castro B. In: River JE, Marchall GR, editors. Peptides: chemistry, structure and biology. Escon: Leiden; 1990. p. 885-8.

[9] De Yang B, Chen Q, Schmidt AP, Anderson GM, Wang JM, Wooters J, et al. LL-37, the neutrophil granule- and epithelial cell-derived cathelicidin, utilizes formyl peptide receptor-like 1 (FPRL1) as a receptor to chemoattract human peripheral blood neutrophils, monocytes, and $\mathrm{T}$ cells. J Exp Med 2000;192:1069-74.

[10] Doherty-Kirby. Lajoie GA. In: Kates SA, Albericio F, editors. Solid phase synthesis. New York: Marcel Dekker Inc.; 2000. p. 129-95.

[11] Fields GB, Noble RL. Solid phase peptide synthesis utilizing 9-fluorenylmethoxycarbonyl amino acids. Int J Peptide Protein Res 1990;35:161-214.

[12] Gudmundsson GH, Agerberth B, Odeberg J, Bergman T, Olsson B, Salcedo R. The human gene FALL39 and processing of the cathelin precursor to the antibacterial peptide LL-37 in granulocytes. Eur J Biochem 1996;238:325-32.

[13] Hancock REW. In: Lorian V, editor. Antibiotics in laboratory medicine Amsterdam. Baltimore: Williams and Wilkins; 1996. p. 52-111.

[14] Kaliner MA, Osguthorpe JD, Fireman P, Anon J, Georgitis J, Davis ML, et al. Sinusitis: bench to bedside. Current findings, future directions. J Allergy Clin Immunol 1997;99:S829-47.

[15] Kita H, Himi T. Cytokine and chemokine induction using cell wall component and toxin derived from gram-positive bacteria in the rat middle ear. Acta Otolaryngol (Stockh) 1999;119:446-52.

[16] Klein JO. State-of-the-art clinical article. Clin Infect Dis 1994;19:823-33.

[17] Klein JO. Clinical implications of antibiotic resistance for management of acute otitis media. J Lab Clin Med 2000;135:220-4.

[18] Koczulla AR, Bals R. Antimicrobial peptides: current status and therapeutic potential. Drugs 2003;63:389-406.

[19] Koenderman L, Kok PT, Hamelink ML, Verhoeven AJ, Bruijnzeel PL. An improved method for the isolation of eosinophilic granulocytes from peripheral blood of normal individuals. J Leukoc Biol 1988;44:79-86.

[20] Larrick JW, Hirata M, Balint RF, Lee J, Zhong J, Wright SC. Human CAP18: a novel antimicrobial lipopolysaccharidebinding protein. Infect Immun 1995;63:1291-7.

[21] Lee VHL. Enzymatic barriers to peptide and protein absorption. CRC Crit Rev Ther Drug Carrier Syst 1988;5:69-97.

[22] McCormick JB. Epidemiology of emerging/re-emerging antimicrobial-resistant bacterial pathogens. Curr Opin Microbiol 1998;1:125-9.

[23] Murakami M, Lopez-Garcia B, Braff M, Dorschner RA, Gallo RL. Postsecretory processing generates multiple cathelicidins for enhanced topical antimicrobial defense. J Immunol 2004;172:3070-7.
[24] Nagaoka I, Hirota S, Niyonsaba F, Hirata M, Adachi Y, Tamura $\mathrm{H}$, et al. Augmentation of the lipopolysaccharideneutralizing activities of human cathelicidin CAP18/LL-37derived antimicrobial peptide by replacement with hydrophobic and cationic amino residues. Clin Diagn Lab Immunol 2002;9:972-82.

[25] Nell MJ, Grote JJ. Structural changes in the rat middle ear mucosa due to endotoxin and Eustachian tube obstruction Eur Arch Otorhinolaryngol 1999;256:167-72.

[26] Nell MJ, Grote JJ. Effects of bacterial toxins on air-exposed cultured human respiratory sinus epithelium. Ann Otol Rhinol Laryngol 2003;112:461-8.

[27] Niyonsaba F, Iwabuchi K, Someya A, Hirata M, Matsuda H, Ogawa $\mathrm{H}$, et al. A cathelicidin family of human antibacterial peptide LL-37 induces mast cell chemotaxis. Immunology 2002;106:20-6.

[28] Ohashi Y, Nakai Y, Esaki Y, Ohno Y, Sugiura Y, Okamoto H. Experimental otitis media with effusion induced by lipopolysaccharide from Klebsiella pneumoniae. Mucociliary pathology of the Eustachian tube. Acta Otolaryngol (Stockh) 1991;105-15. Suppl. 486.

[29] Patrzykat A, Zhang L, Mendoza V, Iwama GK, Hancock RE. Synergy of histone-derived peptides of coho salmon with lysozyme and flounder pleurocidin. Antimicrob Agents Chemother 2001;45:1337-42.

[30] Powell MF, Stewart T, Otvos L, Urge L, Gaeta FCA, Sette A, et al. Peptide stability in drug development II. Effect of single amino acid substitution and glycosylation on peptide reactivity in human serum. Pharm Res 1993;10:1268-73.

[31] Rapp W, Zhang L, Bayer E. In: Epton R, editor. Innovation and perspectives in solid phase peptide synthesis. Birmingham: SPCC (UK) Ltd.; 1990. p. 205-10.

[32] Russell PT, Church CA, Jinn TH, Kim DJ, John EO, Jung TT. Effects of common topical otic preparations on the morphology of isolated cochlear outer hair cells. Acta Otolaryngol 2001;121:135-9.

[33] Schluesener HJ, Radermacher S, Melms A, Jung S. Leukocytic antimicrobial peptides kill autoimmune T cells. J Neuroimmunol 1993;47:199-202.

[34] Scott MG, Davidson DJ, Gold MR, Bowdish D, Hancock RE. The human antimicrobial peptide LL-37 is a multifunctional modulator of innate immune responses. J Immunol 2002;169:3883-91.

[35] Sheppard RC, Williams BJ. Acid-labile resin linkage agents for use in solid phase peptide synthesis. Int J Peptide Protein Res 1982;20:451-4.

[36] Shimizu M, Shigeri Y, Tatsu Y, Yoshikawa S, Yumoto N. Enhancement of antimicrobial activity of neuropeptide $Y$ by N-terminal truncation. Antimicrob Agents Chemother 1998;42:2745-6.

[37] Skotnicka B, Hassmann E. Cytokines in children with otitis media with effusion. Eur Arch Otorhinolaryngol 2000;257:323-6.

[38] Storm DR, Rosenthal KS, Swanson PE. Polymyxin and related peptide antibiotics. Annu Rev Biochem 1977;46:723-45.

[39] Tanaka F, Whitworth CA, Rybak LP. Influence of $\mathrm{pH}$ on the ototoxicity of cisplatin: a round window application study. Hear Res 2003;177:21-31.

[40] Termen S, Tollin M, Olsson B, Svenberg T, Agerberth B, Gudmundsson GH. Phylogeny, processing and expression of the rat cathelicidin rCRAMP: a model for innate antimicrobial peptides. Cell Mol Life Sci 2003;60:536-49.

[41] Tjabranga GS, Aarbiou J, Ninaber DK, Drijfhout JW, Sørensen OE, Borregaard N, et al. The antimicrobial peptide LL-37 activates innate immunity at the airway epithelial surface by transactivation of the epidermal growth factor receptor. J Immunology 2003;171:6690-6. 
[42] Travis SM, Anderson NN, Forsyth WR, Espiritu C, Conway BD, Greenberg EP, et al. Bactericidal activity of mammalian cathelicidin-derived peptides. Infect Immun 2000;68:2748-55.

[43] van der Meide PH, Joosten AM, Hermans P, Kloosterman TC, Olsson T, de Labie MCDC. Assessment of the inhibitory effect of immunosuppressive agents on rat $\mathrm{T}$ cell interferon- $\gamma$ production using an ELISPOT assay. J Immunol Methods 1991;144:203-13.

[44] van Wetering S, Mannesse-Lazeroms SP, van Sterkenburg MA, Daha MR, Dijkman JH, Hiemstra PS. Effect of defensins on interleukin-8 synthesis in airway epithelial cells. Am J Physiol 1997;272:L888-96.

[45] Wald ER, Guerra N, Byers C. Upper respiratory tract infections in young children: duration and frequency of complications. Pediatrics 1991;87:129-33.

[46] Yoon J-H, Kim K-S, Kim HU, Alderman Linton J, Lee J-G. Effects of TNF- $\alpha$ and IL- $1 \beta$ on mucin, lysozyme IL- 6 and IL-8 in passage-2 normal human nasal epithelial cells. Acta Otolaryngol (Stockh) 1999;119:905-10.

[47] Zanetti M. Cathelicidins, multifunctional peptides of the innate immunity. J Leukoc Biol 2004;75:39-48. 